\title{
MULTIPOINT INITIAL-FINAL VALUE PROBLEM FOR HOFF EQUATION IN QUASI-SOBOLEV SPACES
}

\author{
N. N. Solovyova ${ }^{1}$, nsolowjowa@mail.ru, \\ S. A. Zagrebina ${ }^{1}$,zagrebina_sophiya@mail.ru \\ ${ }^{1}$ South Ural State University, Chelyabinsk, Russian Federation
}

We consider an analog of the linear Hoff equation in quasi-Sobolev spaces with multipoint initial-final value condition. The research is based on the abstract results obtained for the Sobolev type equation with multipoint initial-final value condition in the quasi-Banach spaces of sequences. The unique solvability of the studied problem is obtained.

Keywords: multipoint initial-final value problem; quasi-Banach space of sequences; splitting theorem; Hoff equation.

\section{Introduction}

We consider a solvability in quasi-Sobolev spaces for an analog of the linearized homogeneous Hoff equation [1]

$$
(\lambda+\Lambda) u_{t}=\alpha u, \quad \lambda, \alpha \in \mathbb{R}
$$

with the so-called multipoint initial-final value condition

$$
\sum_{k: \mu_{k} \in \sigma_{j}^{L}(M)}\left\langle u\left(\tau_{j}\right)-u_{j}, e_{k}\right\rangle e_{k}=0, \quad j=\overline{0, n},
$$

where $\tau_{j} \in \mathbb{R}_{+}\left(\tau_{0}=0, \tau_{j}<\tau_{j+1}, j=\overline{0, n-1}\right)$ and $e_{k}=(0,0, \ldots, 0,1,0, \ldots)$, such that 1 takes the place with number " $k^{\prime \prime}$.

Our research is based on the results obtained by authors for the problem

$$
\begin{gathered}
L \dot{u}=M u+f, \\
P_{j}\left(u\left(\tau_{j}\right)-u_{j}\right)=0, j=\overline{0, n},
\end{gathered}
$$

such that the equation (1) with the condition (2) is reduced to this problem, where $P_{j}$ are relatively spectral projectors which will be defined further.

On the one hand, history of the problem (3), (4) for $n=1$ begins in [2], where the problem is called Verigin problem. On the other hand, independently in [3] the problem is called the conjugating problem. However, in both cases, spectral projectors of the operator $L$ are considered instead of the relatively spectral projectors $P_{j}$. In addition, it is assumed that $L$ is self-conjugate. First results of researches of the problem (3), (4) are presented in [4], where the special case of the problem (3), (4) is considered. Note that this case has more rigid conditions for $L$-spectrum of the operator $M$ than our case. The term "initial-finite value problem" was proposed by S.A. Zagrebina (see, for example, [6]). In [7] the problem (1), (2) is considered in Sobolev spaces. Article contains three parts besides introduction and references. The first part presents necessary concepts and examples, given 
by G.A. Sviridyuk and J.K. Al-Delfi in [8] and M.A. Sagadeeva and F.L. Hasan in [9]. Also, the results from [10], which are continuation of a series of papers by S.A. Zagrebina, are presented. The second part contains main results of the research of an analog for the linear Hoff equation in quasi-Sobolev spaces of sequences with the multipoint initial-final value condition. Here the abstract results, obtained earlier in the quasi-Banach spaces of sequences, are used. Results of researches of quasi-Sobolev spaces obtained by J.K. Al-Delfi [11] are taken into account.

\section{Multipoint Initial-Final Value Problem in Quasi-Sobolev Spaces}

Definition 1. Let $\mathfrak{U}$ be a real-valued lineal; an ordered couple $(\mathfrak{U} ; \mathfrak{U}\|\cdot\|)$ is called $a$ quasinormed space, if

(i) for all $u \in \mathfrak{U}$ the inequality $\mathfrak{u}\|u\| \geq 0$ holds, where $\mathfrak{U}\|u\|=0$ if and only if $u=\mathbf{0}$, where $\mathbf{0} \in \mathfrak{U}$

(ii) for all $u \in \mathfrak{U}$ and for all $\alpha \in \mathbb{R}$ the equality $\mathfrak{U}\|\alpha \cdot u\|=|\alpha| \cdot \mathfrak{u}\|u\|$ holds;

(iii) for all $u, v \in \mathfrak{U}$ the inequality $\mathfrak{u}\|u+v\| \leq C(\mathfrak{u}\|u\|+\mathfrak{u}\|v\|)$ holds, where the constant $C \geq 1$ and also doesn't depend neither on $u$, nor on $v$.

Definition 2. A complete quasinormed space is called a quasi-Banach space.

Example 1. Consider spaces

$$
l_{p}^{m}=\left\{x=\left\{x_{k}\right\}: \sum_{k=1}^{\infty}\left(\lambda_{k}^{\frac{m}{2}}\left\|x_{k}\right\|\right)^{p}<+\infty\right\},
$$

where $\quad m \in \mathbb{R}, \quad \lambda_{k}$ is nondecreasing sequence of positive numbers such that $\lim _{k \rightarrow \infty} \lambda_{k}=$ $+\infty$. Note that $l_{p}^{m}$ are quasi-Banach spaces for $p \in(0,+\infty)$, but they are Banach spaces for $p \in[1,+\infty)$. (This fact was proved in $[8,11]$ )

Consider the Laplace quasi-operator $\Lambda x=\lambda_{k} x_{k}, x \in l_{p}^{m}$. An operator $\Lambda: l_{p}^{m+2} \rightarrow l_{p}^{m}$ is linear, bounded and continuous invert for all $m \in \mathbb{R}, \quad q \in \mathbb{R}_{+}$.

Let $\mathfrak{U}$ and $\mathfrak{F}$ be quasi-Banach spaces, operator $L \in \mathcal{L}(\mathfrak{U} ; \mathfrak{F})$ be lineal and continuous, operator $M \in \mathcal{C l}(\mathfrak{U} ; \mathfrak{F})$ is lineal, closed and densely defined in space $\mathfrak{U}$, and also the operator $M$ is $(L, p)$-bounded [9]. We consider the linear homogeneous Sobolev type equation

$$
L \dot{u}=M u
$$

Lemma 1. [9] Let operator $M$ be $(L, p)$-bounded, then operators

$$
P=\frac{1}{2 \pi i} \int_{\gamma}(\mu L-M)^{-1} L d \mu \in \mathcal{L}(\mathfrak{U}) \quad \text { and } \quad Q=\frac{1}{2 \pi i} \int_{\gamma} L(\mu L-M)^{-1} d \mu \in \mathcal{L}(\mathfrak{F})
$$

are projectors.

Suppose that $\mathfrak{U}^{0}=\operatorname{ker} P, \mathfrak{F}^{0}=\operatorname{ker} Q, \mathfrak{U}^{1}=\operatorname{im} P, \mathfrak{F}^{1}=\operatorname{im} Q$. Let $L_{k}\left(M_{k}\right)$ be a restrict of the operator $L(M)$ on $\mathfrak{U}^{k}\left(\operatorname{domM} \cap \mathfrak{U}^{k}\right), k=0,1$. Lemma 1 provides that $\mathfrak{U}=\mathfrak{U}^{0} \oplus \mathfrak{U}^{1}$ and $\mathfrak{F}=\mathfrak{F}^{0} \oplus \mathfrak{F}^{1}$. 
Theorem 1. (the splitting theorem by G.A. Sviridyuk) Let operator $M$ be $(L, p)$-bounded. Then

(i) operators $L_{k}, M_{k} \in \mathcal{L}\left(\mathfrak{U}^{k} ; \mathfrak{F}^{k}\right), k=0,1$;

(ii) there exist operators $L_{1}^{-1} \in \mathcal{L}\left(\mathfrak{F}^{1} ; \mathfrak{U}^{1}\right)$ and $M_{0}^{-1} \in \mathcal{L}\left(\mathfrak{F}^{0} ; \mathfrak{U}^{0}\right)$.

Theorem 2. Let operator $M$ be $(L, p)$-bounded, $p \in\{0\} \cup \mathbb{N}$. Then there exists the unique resolving group of the equation (5), which has the form

$$
U^{t}=\frac{1}{2 \pi i} \int_{\gamma}(\mu L-M)^{-1} L e^{\mu t} d \mu, t \in \mathbb{R}
$$

where $\gamma=\{\mu \in \mathbb{C}:|\mu|=r>a\}$ is a closed contour.

The unique resolving group of the equation (5) can be not unique holomorphic degenerate group of this equation. Consider the condition

$$
\left\{\begin{array}{c}
\sigma^{L}(M)=\bigcup_{j=0}^{n} \sigma_{j}^{L}(M), n \in \mathbb{N}, \text { and } \sigma_{j}^{L}(M) \neq \emptyset, \text { there exists } \\
\text { a closed contour } \gamma_{j} \subset \mathbb{C}, \text { which bounds the domain } D_{j} \supset \sigma_{j}^{L}(M), \\
\text { such that } \overline{D_{j}} \cap \sigma_{0}^{L}(M)=\emptyset, \overline{D_{k}} \cap \overline{D_{l}}=\emptyset \forall j, k, l=\overline{1, n}, k \neq l .
\end{array}\right.
$$

Theorem 3. Let operator $M$ be (L,p)-bounded and the condition (6) is satisfied. Then there exists holomorphic degenerate groups of the equation (5).

Corollary 1. Under the conditions of Theorem 3,

(i) $U^{t} U_{j}^{s}=U_{j}^{s} U^{t}=U_{j}^{s+t}$ for all $s, t \in \mathbb{R}, j=\overline{1, n}$;

(ii) $U_{k}^{t} U_{l}^{s}=U_{l}^{s} U_{k}^{t}=\mathbb{O}$ for all $s, t \in \mathbb{R}, k, l=\overline{1, n}, k \neq l$.

Let $U_{0}^{t}=U^{t}-\sum_{k=1}^{n} U_{k}^{t}, t \in \mathbb{R}$ be holomorphic degenerate group of the equation (5)

Remark 1. Consider group unit elements $P_{j}=U_{j}^{0}=\frac{1}{2 \pi i} \int_{\gamma_{j}}(\mu L-M)^{-1} L d \mu, \quad j=\overline{0, n}$, constructed by the condition (6) for the holomorphic degenerate groups $U_{j}^{t}: t \in \mathbb{R}, j=\overline{0, n}$ of the equation (5). It is obviously that

(i) $P P_{j}=P_{j} P=P_{j}, j=\overline{0, n}$;

(ii) $P_{k} P_{l}=P_{l} P_{k}=\mathbb{O}, k, l=\overline{0, n}, k \neq l$.

Assume that the subspaces $\mathfrak{U}^{1 j}=\operatorname{im} P_{j}, \mathfrak{F}^{1 j}=\operatorname{im} Q_{j}, j=\overline{0, n}$. Then $\mathfrak{U}^{1}=\bigoplus_{j=0}^{n} \mathfrak{U}^{1 j}$ and $\mathfrak{F}^{1}=\bigoplus_{j=0}^{n} \mathfrak{F}^{1 j}$. Let $L_{1 j}$ be a restriction of the operator $L$ to the $\mathfrak{U}^{1 j}, j=\overline{0, n}$, and $M_{1 j}$ be a restriction of the operator $M$ to the $\operatorname{dom} M \cap \mathfrak{U}^{1 j}, j=\overline{0, n}$.

Let us take $\tau_{j} \in \mathbb{R}_{+}\left(\tau_{0}=0, \tau_{j}<\tau_{j+1}, j=\overline{0, n-1}\right)$, vectors $u_{j} \in \mathfrak{U}, j=\overline{0, n}$, vector-function $f \in C^{\infty}((0, \tau) ; \mathfrak{F})$ and consider the linear non-homogeneous Sobolev type equation (3). 
Definition 3. A vector-function $u \in C^{\infty}((0, \tau) ; \mathfrak{U})$, satisfying to the equation (3), is called a solution of the equation (3). A solution $u=u(t), t \in\left(0, \tau_{n}\right)$ of the equation (3), satisfying to the multipoint initial-final value condition (4) is called a solution to the multipoint initial-final value problem for the equation (4).

Theorem 4. [9] (The generalized spectral theorem). Let operators $L \in \mathcal{L}(\mathfrak{U} ; \mathfrak{F})$ and $M \in$ $\mathcal{C l}(\mathfrak{U} ; \mathfrak{F})$, and operator $M$ be $(L, p)$-bounded, and the condition (6) is fulfilled. Then

(i) operators $L_{1 j}, M_{1 j} \in \mathcal{L}\left(\mathfrak{U}^{1 j} ; \mathfrak{F}^{1 j}\right), j=\overline{0, n}$;

(ii) there exist operators $L_{1 j}^{-1} \in \mathcal{L}\left(\mathfrak{F}^{1 j} ; \mathfrak{U}^{1 j}\right)$

Theorem 5. [9] Let operator $M$ be $(L, p)$-bounded, and the condition (6) is fulfilled. Then for every $\left.f \in C^{\infty}((0, \tau) ; \mathfrak{F})\right), u_{j} \in \mathfrak{U}, j=\overline{0, n}$ there exists the unique solution to the problem (3), (4), which has form

$$
u(t)=-\sum_{q=0}^{p}\left(M_{0}^{-1} L_{0}\right)^{q} M_{0}^{-1}(\mathbb{I}-Q) f^{(q)}(t)+\sum_{j=0}^{n} U_{j}^{t-\tau_{j}} u_{j}+\sum_{j=0}^{n} \int_{\tau_{j}}^{t} U_{j}^{t-s} L_{1 j}^{-1} Q_{j} f(s) d s .
$$

Therefore, the uniqueness of solution to the problem (3), (4) is proved in [9].

\section{The Analogue of Hoff Equation in Quasi-Sobolev Spaces}

Consider the analogue of the linear Hoff equation

$$
(\lambda+\Lambda) u_{t}=\alpha u, \quad \lambda, \alpha \in \mathbb{R},
$$

in the quasi-Sobolev spaces $\mathfrak{U}=l_{q}^{r+2}$ and $\mathfrak{F}=l_{q}^{r}$ where $r \in \mathbb{R}$ and $q \in \mathbb{R}_{+}$. Let operators $L=\lambda+\Lambda$ and $M=\alpha \mathbb{I}$, then the operators $L, M \in \mathcal{L}\left(l_{q}^{r+2}, l_{q}^{r}\right)$.

Let sequence $\left\{\lambda_{k}\right\} \subset \mathbb{R}_{+}$, be such that $\lim _{k \rightarrow \infty} \lambda_{k}=+\infty$. Degrees of the Laplace quasioperator $\Lambda^{n} u=\left\{\lambda_{k}^{n} u_{k}\right\}, n \in \mathbb{N}$ are lineal continuous operators from the quasi-Sobolev space $l_{q}^{r+2}$ to the quasi-Sobolev space $l_{q}^{r}(0<q<1, r \in \mathbb{R})$.

Lemma 2. Let $l_{q}^{r+2}$, and $l_{q}^{r}$, where $r \in \mathbb{R}$ and $q \in \mathbb{R}_{+}$. Then for all $\lambda \in \mathbb{R}$ and $\alpha \in \mathbb{R} \backslash\{0\}$ the operator $M$ is $(L, 0)$-bounded, moreover $L$-spectrum of the operator $M$ has the form

$$
\sigma^{L}(M)=\left\{\mu \in \mathbb{C}: \mu_{k}=\frac{\alpha}{\lambda+\lambda_{k}}, k: \lambda_{k} \neq \lambda\right\} .
$$

Let the condition (6) be fulfilled, then Lemma (2) provides

Theorem 6. Let $\lambda \in \mathbb{R}, \alpha \in \mathbb{R} \backslash\{0\}$, and the condition (6) is fulfilled. Then for every analytic vector-function $g:[0, \tau] \rightarrow l_{q}^{r}$, as well as for every $u_{j} \in l_{q}^{r+2}, j=\overline{0, n}$, there exist the unique solution $u \in C^{1}\left([0, \tau] ; l_{q}^{r+2}\right)$ to the problem (8) of the form

$$
\begin{gathered}
u(t)=\sum_{l \in \mathbb{N} ; \lambda_{l}=-\lambda} \frac{\left\langle g(t), e_{l}\right\rangle}{\alpha} e_{l}+\sum_{\mu_{k} \in \sigma_{0}^{L}(M)}\left(e^{\mu_{k} t}\left\langle u_{0}, e_{k}\right\rangle+\int_{0}^{t} \frac{\left\langle g(s), e_{k}\right\rangle}{\lambda+\lambda_{k}} e^{\mu_{k}(t-s)} d s\right) e_{k}+ \\
\quad+\sum_{j=1}^{n} \sum_{\mu_{k} \in \sigma_{1}^{L} M}\left(e^{\left.\mu_{k(t-\tau)}\left\langle u_{j}, e_{k}\right\rangle-\int_{\tau}^{t} \frac{\left\langle g(s), e_{k}\right\rangle}{\lambda+\lambda_{k}} e^{\mu_{k}(t-s)} d s\right) e_{k} .}\right.
\end{gathered}
$$

Where $\mu_{k}$ is from L-spectrum of the operator $M$. 


\section{References}

1. Hasan F.L. Solvability of Iinitial Problems for One Class of Dymamical Equations Quasi-Sobolev Spaces. Journal of Computational and Engineering Mathematics, 2015, vol.2, no. 3., pp. 34-42. doi: 10.14529/jcem150304

2. Pankov A.A., Pankova T.E. [The Nonlinear Evolutionary Equations with Irreversible Operator Coefficient at a Derivative]. Reports of Academy of Sciences of Ukraine, 1993, no. 9, pp. 18-20. (in Russian)

3. Pyatkov S.G. Operator Theory. Nonclassical Problems. Utrecht; Boston; Koln, VSP, 2002.

4. Sviridyuk G.A., Zagrebina S.A. Verigin's Problem for Linear Equations of the Sobolev Type with Relatively p-Sectorial Operators. Differential Equations, 2002, vol. 38, no. 12., pp. 1745-1752. doi: 10.1023/A:1023812213901

5. Sviridyuk G.A. On the General Theory of Operator Semigroups. Russian Mathematical Surveys, 1994, vol. 49, no. 4, pp. 45-74. doi: 10.1070/RM1994v049n04ABEH002390

6. Zagrebina S.A. The Initial-Finish Problem for the Navier-Stokes Linear System. Bulletin of the South Ural State University. Series: Mathematical Modelling, Programming and Computer Software, 2011, no. 4 (221), issue 7, pp. 35-39. (in Russian)

7. Zagrebina S.A. Multipoint Initial-Final Problem for Linear Hoff Model. Bulletin of the South Ural State University. Series: Mathematical Modelling, Programming and Computer Software, 2012, no. 11, pp. 4-12. (in Russian)

8. Sviridyuk G.A., Al-Delfi J.K. [Laplace Quasioperator in Quasi-Sobolev Spaces]. Differential Equations. Function Space.Theory of Approximations: International conference. Novosibirsk, 2013, pp. 247. (in Russian)

9. Sagadeeva M.A., Hasan F.L. Existence of Invariant Spaces and Exponential Dichotomies of Solutions of Dynamical Sobolev Type Equations in Quasi-Banach Spaces. Bulletin of the South Ural State University. Series: Mathematics. Mechanics. Physics, 2015. vol. 7, no. 4, pp. 46-53. doi: 10.14529/mmph150406 (in Russian)

10. Safiullina D.R., Solovyova N.N. [Sobolev Type Equation in Quasi-Banach Spaces with Multipoint Initial-Final Condition]. South Ural Youth School on Mathematical Modeling: collection works of the III All-Russian scientific conference. Chelyabinsk, 2016, pp. 175-180. (in Russian)

11. Al-Delfi J.K. Quasi-Sobolev spaces $l_{p}^{m}$. Bulletin of the South Ural State University. Series: Mathematics. Mechanics. Physics, 2013, vol. 5, no. 1, pp. 107-109. (in Russian)

Natalya N. Solovyova, Graduate Student, Department of Mathematical Equations Physics, South Ural State University (Chelyabinsk, Russian Federation), nsolowjowa@mail.ru

Sophiya A. Zagrebina, DSc (Math), Head of Department Mathematical and Computer Modelling, South Ural State University (Chelyabinsk, Russian Federation), zagrebina_sophiya@mail.ru

Received June 7, 2017 


\title{
МНОГОТОЧЕЧНОЕ НАЧАЛЬНО-КОНЕЧНОЕ УСЛОВИЕ ДЛЯ УРАВНЕНИЯ ХОФФА В КВАЗИСОБОЛЕВЫХ ПРОСТРАНСТВАХ
}

\author{
Н.Н. Соловъева, С.А. Загребина
}

\begin{abstract}
Данная работа посвящена исследованию аналога линейного уравнения Хоффа в квазисоболевых пространствах с многоточечным начально-конечным условием. Исследование проведено на основе абстрактных результатов, полученных для уравнения соболевского типа с многоточечным начально-конечным условием в квазибанаховых пространствах последовательностей. Приведена идея доказательства существования и единственности решения поставленной задачи, а также приведен его вид.

Ключевые слова: многоточечная начально-конечная задача, квазибанаховы пространства последовательностей, теорема о расщеплении, уравнение Хоффа.
\end{abstract}

\section{Литература}

1. Hasan, F.L. Solvability of initial problems for one class of dymamical equations quasi-sobolev spaces / F.L. Hasan // Journal of Computational and Engineering Mathematics. - 2015. - T. 2, № 3. - P. 34-42.

2. Панков, А.А. Нелинейные эволюционные уравнения с необратимым операторным коэффициентом при производной / А.А. Панков, Т.Е. Панкова // Доклады Академии наук Украины. - 1993. - № 9. - С. 18-20.

3. Pyatkov, S.G. Operator Theory. Nonclassical Problems / S.G. Pyatkov. - Utrecht, Boston, Koln: VSP, 2002.

4. Свиридюк, Г.А. Задача Веригина для линейных уравнений соболевского типа с относительно p-секториальными операторами / Г.А. Свиридюк, С.А. Загребина // Дифференциальные уравнения. - 2002. - Т. 38, № 12. - С. 1646-1652.

5. Свиридюк, Г.А. К общей теории полугрупп / Г.А. Свиридюк // Успехи математических наук. - 1994. - Т. 49, № 4. - С. 47-74.

6. Загребина, С.А. Начально-конечная задача для линейной системы НавьеСтокса / С.А. Загребина // Вестник ЮУрГУ. Серия: Математическое моделирование и программирование. - 2011. -№ 4 (221), вып. 7. - С. 35-39.

7. Загребина, С.А. Многоточечная начально-конечная задача для линейной модели Хоффа / С.А. Загребина // Вестник ЮУрГУ. Серия: Математическое моделирование и программирование. - 2012. - № 11. - С. 4-12.

8. Свиридюк, Г.А. Квазиоператор Лапласа в квазисоболевых пространствах / Г.А. Свиридюк, Дж.К. Аль-Делфи // Дифференциальные уравнения. Функциональные пространства. Теория приближений: тез. докл. международ. конф. Новосибирск, 2013. - С. 247. 
9. Сагадеева, М.А. Существование инвариантных подпространств и экспоненциальных дихотомий решений динамических уравнений соболевского типа в квазибанаховых пространствах / М.А. Сагадеева, Ф.Л. Хасан // Вестник ЮУрГУ. Серия: Математика. Механика. Физика. - 2015. - Т. 7, № 4. - С. 46-53.

10. Сафиуллина, Д.Р. Уравнение соболевского типа в квазибанаховых пространствах с многоточечным начально-конечным условием / Д.Р. Сафиуллина, Н.Н. Соловьёва // Южно-Уральская молодежная школа по математическому моделированию: сб. тр. III Всерос. науч.-практ. конф. - Челябинск, 2016. - С. 175-180.

11. Аль-Делфи, Дж.К. Квазисоболевы пространства $l_{p}^{m} /$ Дж.К. Аль-Делфи // Вестник ЮУрГУ. Серия Математика. Механика. Физика. - 2013. - Т. 5, № 1. C. 107-109.

Соловъёва Наталъя Николаевна, магистрант, кафедра уравнений математической физики, Южно-Уральский государственный университет (ә. Челябинск, Российская Федерация), nsolowjowa@mail.ru

Загребина Софъя Александровна, доктор физико-математических наук, заведующий кафедрой математического и компьютерного моделирования, ЮжноУральский государственный университет (г. Челябинск, Российская Федераиия), zagrebina_sophiya@mail.ru

Поступила в редакцию 7 июня 2017 г. 